\title{
Geochemistry of major and trace elements and their environmental significances in core sediments from Bosten Lake, arid northwestern China
}

\author{
Wen LIU, ${ }^{1,2,3}$ Jilili ABUDUWAILI, ${ }^{1,2,3^{*}}$ Long MA ${ }^{1,2,3}$ \\ ${ }^{1}$ State Key Laboratory of Desert and Oasis Ecology, Xinjiang Institute of Ecology and Geography, Chinese Academy of Sciences, \\ Urumqi 830011; ${ }^{2}$ Research Center for Ecology and Environment of Central Asia, Chinese Academy of Sciences, Urumqi 830011; \\ ${ }^{3}$ University of Chinese Academy of Sciences, Beijing 100049, China
}

\begin{abstract}
Geochemical element concentrations of a 41-cm-long sediment core from Bosten Lake were analyzed with grain size, total organic carbon and total inorganic carbon, and environmental evolution over the past $\sim 150$ years was reconstructed. Based on principal component analysis (PCA) and correlation analysis of the elements, three controlling factors for vertical distribution characteristics of elements were identified, the first factor was the combined effects of terrigenous detritus and endogenous carbonate, the second controlling factor was the granularity effects of the lake sediment, the third controlling factor was the input from human activities. A first stage was from the 1870s to the 1950s, Bosten Lake was in a natural state, the deposition rates were relatively low, and the concentrations of Ca, Sr, and $\mathrm{Ba}$ were high. The second stage was from the 1960s to the 1990s, triggered by the inflow of agricultural return water, the sedimentation rates were clearly higher than the former stage, the concentrations of $\mathrm{Al}, \mathrm{Fe}$, and $\mathrm{K}$ increased notably, and $\mathrm{Ca}, \mathrm{Sr}$, and $\mathrm{Ba}$ decreased. The third stage comprised the period since the $2000 \mathrm{~s}$, the scope of human activities has been extended. Enrichment factors of Cd, $\mathrm{Pb}$ and $\mathrm{P}$ of the sediment have increased. The economic development in the basin led to an increase in pollution of the lake. Human impacts on the environmental change were embodied in the enrichment of $\mathrm{Cd}, \mathrm{Pb}$, and $\mathrm{P}$, and the clear decline of biogenic $\mathrm{Ca}$. Sediment geochemistry has faithfully recorded the impacts of human activities on the environmental changes of Bosten Lakes.
\end{abstract}

\section{INTRODUCTION}

Lake sediments are primarily derived from surface materials within the basin and authigenic minerals and the elements in sediments enter the lake from weathering rocks, soil erosion, and anthropogenic sources. The profiles of major and trace elements in lake sediments can carry rich information about the changes in the watershed and lake environment (Boyle et al., 2004; Yang and Rose, 2005; Grosbois et al., 2012). In the past few decades, human activities have played an increasingly role in the environmental changes of lake basins in the arid regions of Central Asia, causing severe damage to fragile ecosystems. In addition, many heavy metals are generally toxic to aquatic life, can be bioaccumulated and cannot

Corresponding author: jili1@ms.xjb.ac.cn

Key words: Bosten Lake; sediment; geochemical elements; multivariate statistical analysis; environmental evolution.

Edited by: Andrea Lami, CNR-IRSA Verbania, Italy

Received: 30 November 2018.

Accepted: 26 March 2019.

This work is licensed under a Creative Commons Attribution NonCommercial 4.0 License (CC BY-NC 4.0).

${ }^{\circ}$ Copyright: the Author(s), 2019

Licensee PAGEPress, Italy

J. Limnol., 2019; 78(2): 201-209

DOI: 10.4081/jlimnol.2019.1875 be degraded, and are a long-term human health hazard. Therefore, studies on the concentrations and changing trends of geochemical elements also have ecological significances. The analysis of sedimentary environment indicators can reconstruct the environmental history which covered the background period before human activities to the period mainly influenced by human activities (Wu et al., 2013a; Ma et al., 2016). This analysis is highly important for evaluating the impact of human activities in the basin, for assessing the environmental quality of the waters and guiding ecological restoration.

Bosten Lake is located in the south slope of Tianshan Mountain of the Xinjiang Uygur autonomous region, and it is the largest inland fresh water lake of China. The Bosten Lake is important for regional ecosystems, and the lake water is the resource of Kongque River, which maintains the ecosystem balance of Lop Nur region. Along with the exploitation of soil and water for the development of agriculture and manufacturing in and around the drainage basin, the ecological environment of Bosten Lake has deteriorated and caused a series of environmental problems (Fan et al., 2000; Zhou et al., 2001; Li and Yuan, 2002). There has been an increasing focus on modern lake environmental changes, including water quality and quantity (Zuo et al., 2006; Wang et al., 2013; Zhang et al., 2013; Guo et al., 2015; Rusuli et al., 2015), and surface lake sediments (Zhang et al., 2009a; Xiao et al., 2010; Chen et al., 2014; Liu et al., 2015). Several studies have also discussed paleo-environmental changes over extended time scales (Mischke and Wünnemann, 2006; Wünnemann et al., 2006; Chen et al., 2008; Huang et al., 2009). The spatial distribution of 
organic carbon in surface sediment and carbon burial over the past century have been used to reveal the important role in the terrestrial carbon cycle (Yu et al., 2015; Yu et al., 2018). However, the study on geochemical element concentrations (including heavy metals) and environmental state from lake sediment in modern times has remained a blank. The aim of this study is to distinguish the sources of the elements with multivariate statistical analysis and to describe the environmental history of Bosten Lake, which will reconstruct the effects of human activities on the lake environment from a geochemical perspective.

\section{METHODS}

\section{Regional setting}

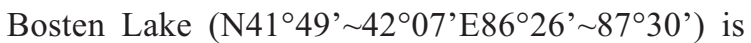
located in the South of Tianshan, Xinjiang Uyghur autonomous region of China, and represent the closing point of the Yanqi Basin, which is a intramontane basin between the southern slopes of the Tianshan mountain and Taklimakan desert. The catchment area of Bosten Lake is approximately $\sim 55,600 \mathrm{~km}^{2}$ (Wang and Dou, 1998) (Fig. 1). In 2008 , the water surface lied at $1050 \mathrm{~m}$ above sea level (asl), the maximum depth of the lake water was 14 $\mathrm{m}$, the lake area was $1005 \mathrm{~km}^{2}$, and the water storage was $59 \times 10^{8} \mathrm{~m}^{3}$ (Wu et al., 2013b). The lake basin has a rather steep slope near the shoreline and is quite flat in the center. The lake water is weakly alkaline and has a high degree of hardness. The discharge of Kaidu River accounts for $84.2 \%$ of the total runoff into the lake, and the mean annual runoff is $34.12 \times 10^{8} \mathrm{~m}^{3}$. The seasonal rivers inflow into the lake include 13 other first order rivers, such as Huangshui River, Qingshui River, Wulasitai River, Quhui River, and WuShen Tara River. The outflow river is Kongque River, which supplies water to Korla City on the way to LopNor. The climate in the basin is a typical temperate arid climate. The mean annual temperature is $8.4^{\circ} \mathrm{C}$, the mean annual precipitation is $94.7 \mathrm{~mm}$, and the potential evaporation is $1800 \mathrm{~mm}$ (Zhou et al., 2014). The Yanqi basin includes four counties: Bohu county, Yanqi county, Heshuo county and Hejing county. There are approximately 26 farmland drainage ditches that enter the lake, which are the main pollution sources to the lake (Sai et al., 2012).

\section{Sample collection and analysis}

To better understand the human impacts to the environmental state of Bosten Lake, a continuous sediment core with a 41-cm length was taken near the major inflow river (Kaidu River) in June 2016 (Fig. 1). A piston percussion corer, fitted with $60 \mathrm{~mm}$ internal diameter Perspex pipes, was used during the sampling. The core sediment had a clear water-sediment interface, which denoted that the occurrence of disturbances was absent during the sampling. The sediment core was immediately sliced into subsamples in 1-cm intervals in the field. All the samples were put into sealable

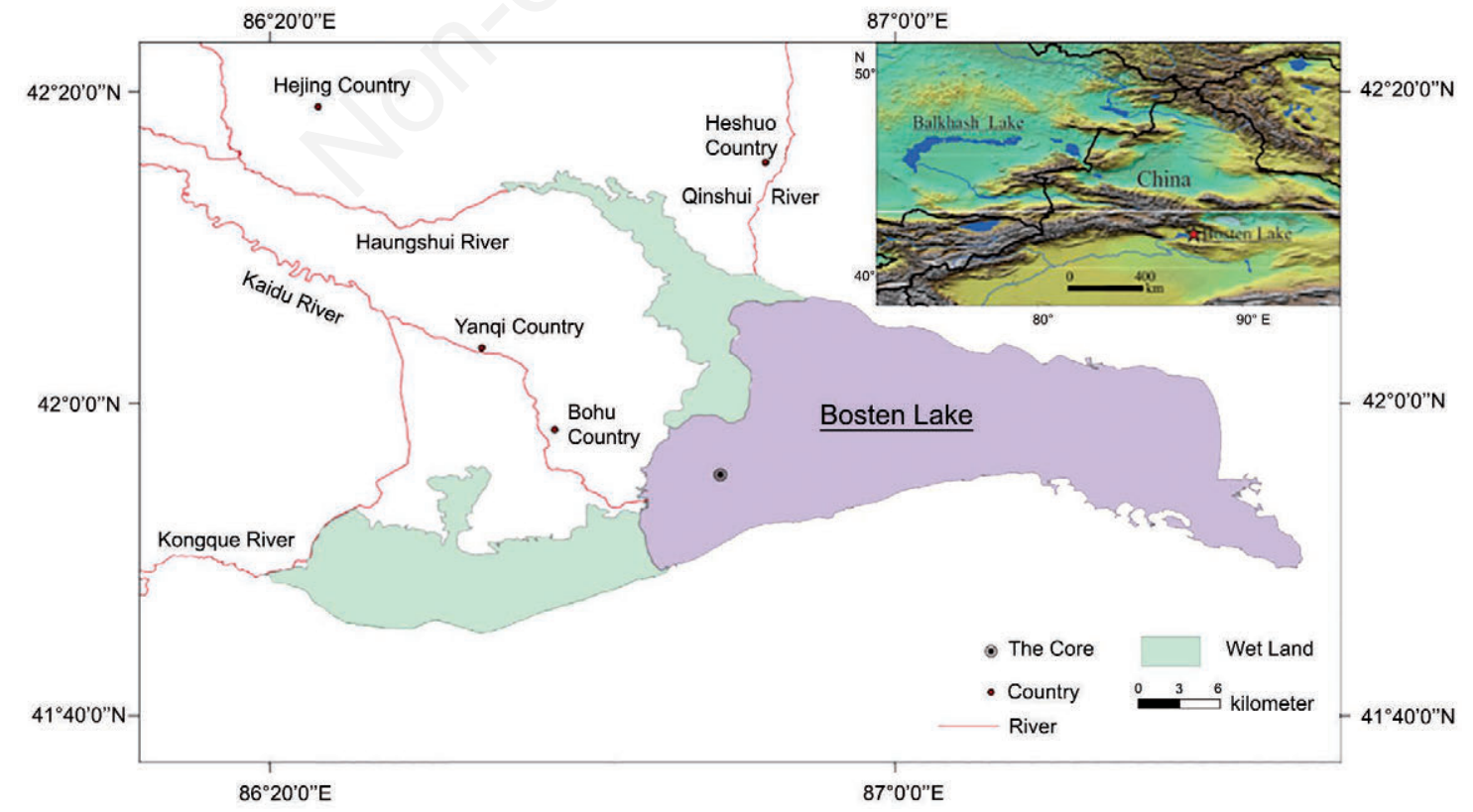

Fig. 1. Geographic Location of Bosten Lake and the sediment core. 
polyethylene bags and kept in an incubator with ice bags, then transported to the laboratory and preserved in the refrigerator at a temperature of $4^{\circ} \mathrm{C}$ before analysis. The samples were dried in an oven at $45^{\circ} \mathrm{C}$. They were first used for dating analysis and then for geochemical analysis.

An age-depth model was established with ${ }^{210} \mathrm{~Pb}$ dating, which was performed using an EG\&G Ortec Gamma Spectrometer, with a low-level germanium detector (EG\&G ORTEC, HPGe GWL). ${ }^{210} \mathrm{~Pb}$ activity was determined by gamma emission at $46.5 \mathrm{keV}$. ${ }^{226} \mathrm{Ra}$ was determined by the $295 \mathrm{keV}$ and $352 \mathrm{keV} \gamma$-rays emitted by its daughter nuclide ${ }^{214} \mathrm{~Pb}$, after 3 weeks of storage in sealed containers to allow radioactive equilibrium.

For the measurement of elemental content, the samples $(\sim 0.125 \mathrm{~g})$ were first digested with $\mathrm{HF}-\mathrm{HNO}_{3}-$ $\mathrm{HClO}_{4}$ in a Berghof MWS-3 microwave digester, and then the residuals were digested with $\mathrm{HNO}_{3}$, and then with $\mathrm{H}_{2} \mathrm{O}_{2}$, in a Teflon baker. Major elements $(\mathrm{Al}, \mathrm{Ca}, \mathrm{Fe}, \mathrm{K}$, $\mathrm{Mg}, \mathrm{Na}$ ) and some trace elements (Ba, Be, Mn, P, Sr, Ti, $\mathrm{Zn}$ and V) were measured by Inductively Coupled Plasma Atomic Emission Spectroscopy (ICP-AES), and trace elements $(\mathrm{Cr}, \mathrm{Co}, \mathrm{Ni}, \mathrm{Cu}, \mathrm{As}, \mathrm{Cd}, \mathrm{Tl}$ and $\mathrm{Pb}$ ) were measured by Inductively Coupled Plasma Mass Spectrometry (ICP-MS). Standard solution SPEX ${ }^{\mathrm{TM}}$ (USA) was used as the standard. Quality control was assured by the analysis of duplicate samples, blanks, and reference materials (GSD-9 and GSD-11). The relative standard deviation was below $3 \%$ for ICP-AES and below $5 \%$ for ICP-MS.

Subsamples for total organic carbon (TOC) were purged with adequate $\mathrm{HCl}(\sim 1 \mathrm{~N})$ to completely remove carbonate and rinsed with distilled water to achieve a neutral state and then freeze-dried. The samples (pretreated with $\mathrm{HCl}$ and untreated) were weighed and packed carefully in tin capsules and then measured with a CE-440 elemental analyzer for TOC and TC, respectively. Analytical precision was based on repeated samples and reference material measurements, and the standard deviation was below $5 \%$. Total inorganic carbon (TIC) was calculated as the difference between TC and TOC.

The sediment samples used for grain-size distribution $(\sim 0.3 \mathrm{~g})$ were pretreated with diluted $\mathrm{HCl}$ and $\mathrm{H}_{2} \mathrm{O}_{2}$ to remove carbonates and organic matters, respectively. Then the residues were washed with deionized water to achieve a neutral $\mathrm{pH}$. A dispersant solution $\left(\mathrm{Na}_{2} \mathrm{PO}_{3}\right)_{6}$ was mixed with the residues and then dispersed by an ultrasonic oscillator for $15 \mathrm{~min}$. Grain size distributions were measured by a Mastersizer 2000 Laser Grain-size Meter; the analytical precision was based on repeated measurements and the relative error was less than $1 \%$. The parameters used in this study include the percentage compositions of clay $(<4 \mu \mathrm{m})$, silt $(4 \sim 16 \mu \mathrm{m}, 16 \sim 32 \mu \mathrm{m}$, $32 \sim 64 \mu \mathrm{m})$ and sand $(>64 \mu \mathrm{m})$.

\section{Data analysis}

Understanding the regional environmental change and pollution history must be based on an accurate chronology. Supported ${ }^{210} \mathrm{~Pb}$ was derived from the decay of in situ ${ }^{226} \mathrm{Ra}$, and unsupported ${ }^{210} \mathrm{~Pb}$ (excess ${ }^{210} \mathrm{~Pb}$, ${ }^{210} \mathrm{~Pb}_{\mathrm{ex}}$ ) was derived from atmospheric fallout, decayed from ${ }^{222} \mathrm{Rn}$. The ${ }^{210} \mathrm{~Pb}_{\mathrm{ex}}$ activity was determined by subtracting supported ${ }^{210} \mathrm{~Pb}$ activity from the total ${ }^{210} \mathrm{~Pb}$ activity $\left({ }^{210} \mathrm{~Pb}_{\mathrm{tot}}\right)$. There are two calculation models based on ${ }^{210} \mathrm{~Pb}_{\text {ex }}$ activity: the CRS model (constant rate of ${ }^{210} \mathrm{~Pb}$ supply) and the CIC model (constant initial concentration of ${ }^{210} \mathrm{~Pb}$ ) (Appleby, 2008). In this study, the sediment rate was calculated by the CRS model, and the average deposition rate was determined by the CIC model.

Multivariate techniques including correlation analysis and principle component analysis were used to evaluate the elemental sources, as calculated by SPSS 20.0 (SPSS Inc., USA). Spearman's correlations were used to evaluate the relationships between the grain size content, TOC, TIC and geochemical element concentrations. PCA was carried out with varimax rotation to identify the potential influencing factors of the geochemical elements. The Kaiser-Meyer-Olkin (KMO) and Bartlett tests were used to evaluate the validity of PCA.

\section{RESULTS}

\section{Sedimentology and chronology}

The core sediment consisted of relatively uniform fine-grained materials (Fig. 2). The content of grain sizes $<4 \mu \mathrm{m}$ was $11.3 \sim 23.85 \%$, with an average of $18.03 \%$. The content of grain sizes $4 \sim 16 \mu \mathrm{m}$ was $34.56 \sim 45.55 \%$, and the mean content was $40.18 \%$. The content of grain sizes $16 \sim 64 \mu \mathrm{m}$ ranged from $32.14 \%$ to $44.49 \%$, and the average value was $36.73 \%$. The content of grain sizes $>64$ $\mu \mathrm{m}$ was $0.22 \sim 14.14 \%$, with a mean value of $5.05 \%$. According to the classification criterion based on clay $(<4$ $\mu \mathrm{m})$, fine silt $(4 \sim 16 \mu \mathrm{m})$ and silt $(16 \sim 63 \mu \mathrm{m})$, the lithology of the sediment was fine silt. There were many shells in the sediment below $23 \mathrm{~cm}$.

As shown in Fig. 2, the specific activity of ${ }^{210} \mathrm{~Pb}_{\text {tot }}$ ranged from $74.27 \sim 448.16 \mathrm{~Bq} \mathrm{~kg}^{-1}$, and ${ }^{226} \mathrm{Ra}$ was between $34.97 \sim 74.13 \mathrm{~Bq} \mathrm{~kg}{ }^{-1} .{ }^{210} \mathrm{~Pb}$ declined to nearly zero at the bottom of the core. The vertical profile of the excessive ${ }^{210} \mathrm{~Pb}$ activity in the sediment cores showed an irregular serrated distribution state, and exhibited an approximately exponential decline with depth, which was similar to the profiles observed in previous studies (Chen et al., 2006; Zhang et al., 2009b; Liao et al., 2014; Yu et al., 2015).

The bottom of the core was dated as $1868 \mathrm{AD}$, and the sediment accumulation rate was from $0.116 \sim 0.255 \mathrm{~g} \mathrm{~cm}^{-2}$ $\mathrm{a}^{-1}$ based on the CRS model. The sediment deposition rates 
were relatively low before the $1960 \mathrm{~s}$, and the average rate was $0.160 \mathrm{~g} \mathrm{~cm}^{-2} \mathrm{a}^{-1}$. However, the sedimentation rate has been higher since the 1960s, and the average value was $0.229 \mathrm{~g} \mathrm{~cm}^{-2} \mathrm{a}^{-1}$. The average linear deposition rate was $0.51 \mathrm{~cm} \mathrm{a}^{-1}$, determined by the CIC model. The sedimentation rate calculated in this study was higher than the former studies (Chen et al., 2006; Liao et al., 2014; Yu et al., 2015), and the high deposition rate was primarily in agreement with the sampling location near the estuary-area of Kaidu River, where more silt and mud was deposited.

\section{Profiles of element concentrations}

Fluctuation curves of elemental content with ages are shown in Fig. 3. The concentration of Al ranged from 2.70 to $3.71 \mathrm{mg} \mathrm{g}^{-1}$, which mainly increased from the bottom to $28 \mathrm{~cm}$ and then declined to the top of the core. The profile of $\mathrm{Al}$ was very similar to those of $\mathrm{K}, \mathrm{Na}, \mathrm{Fe}, \mathrm{Be}$, $\mathrm{Ti}, \mathrm{V}, \mathrm{Co}, \mathrm{Zn}$. The profiles of $\mathrm{Cu}, \mathrm{Mn}, \mathrm{Mg}, \mathrm{Ni}, \mathrm{Cr}, \mathrm{Tl}$ were similar; the concentrations were low and fluctuated from the bottom to $28 \mathrm{~cm}$ and mainly increased to relatively higher concentrations to the top. The vertical distributions of $\mathrm{P}, \mathrm{Pb}, \mathrm{Cd}$ mainly increased from the bottom to the top of the core. The concentration of $\mathrm{Ca}$ ranged from 144 to $188 \mathrm{mg} \mathrm{g}^{-1}$, with high values at the bottom, began to decrease at approximately $28 \mathrm{~cm}$ and then maintained relatively stable values, similar to those of $\mathrm{Ba}$ and $\mathrm{Sr}$. The concentration of As was very high in the upper $1 \mathrm{~cm}$. Apart from the surface peak, the peak in As profile appeared at approximately $\sim 23 \mathrm{~cm}$. TIC content was between $5.17 \%$ and $7.22 \%$, and the mean content was $6.12 \%$, similar to $\mathrm{Ca}$. TOC increased from the bottom to $28 \mathrm{~cm}$, declined at the depth of $20 \mathrm{~cm}$ and then increased to the top.

\section{DISCUSSION}

\section{Characteristics and influencing factors of elements' content}

Principal component analysis and correlation analysis were used to identify the controlling factors of major and trace elements (Morillo et al., 2004; Grosbois et al., 2012;
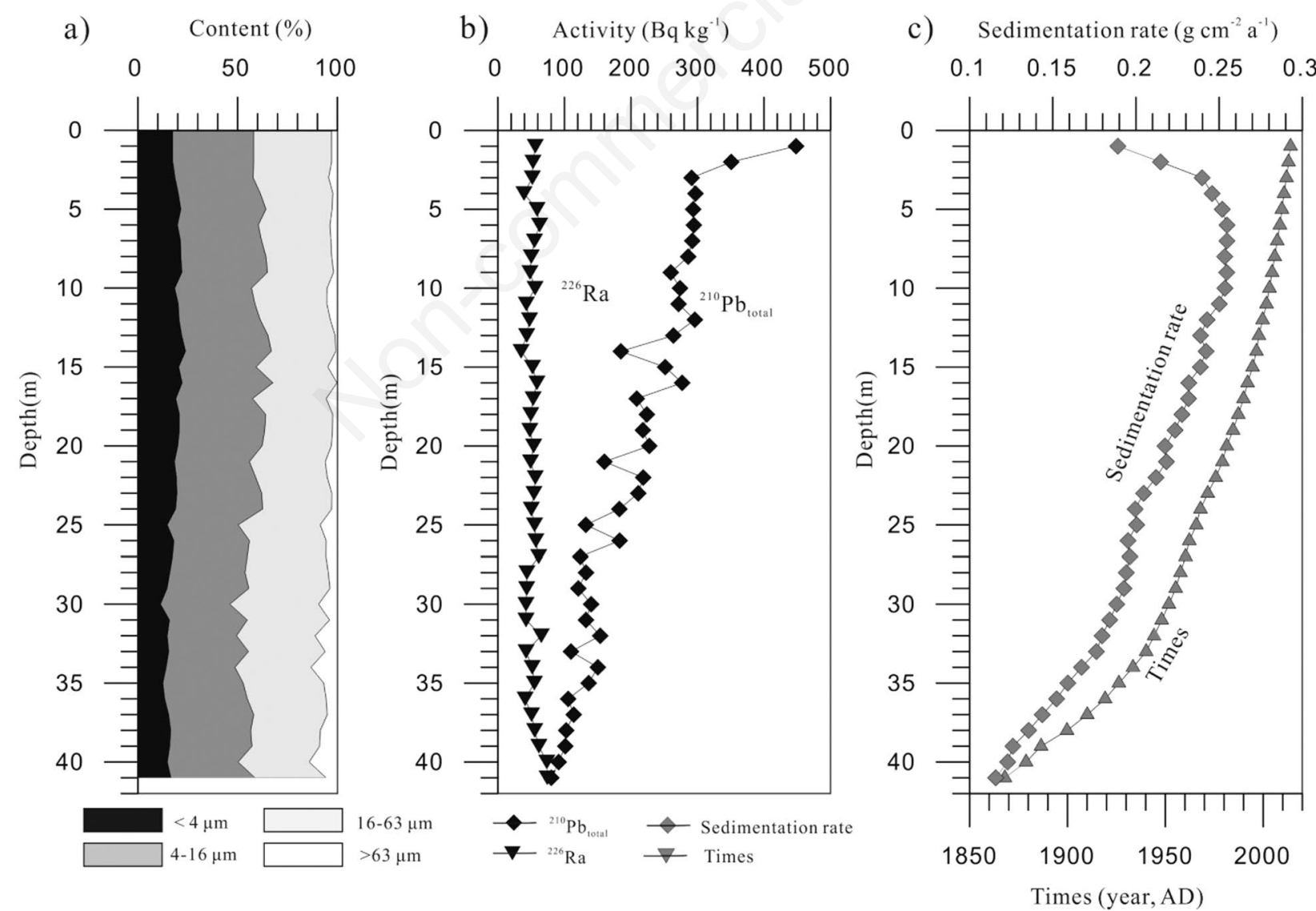

Fig. 2. a) Vertical distributions of sediment texture; b) vertical distributions of $226 \mathrm{Ra}$ and $210 \mathrm{Pbtotal}$; c) ages and sedimentation rates calculated from CRS model. 
Mamat et al., 2014; Liu et al., 2016; Ma et al., 2016). The correlation analysis results were given in Tab. S1. Three principal components, which can explain $87.615 \%$ of the total variance, were extracted, and the composition matrix was shown in Fig. 4. The KMO value was 0.831, the significance of Bartlett's Sphericity was 0, which proved that the result of the analysis was valid.

The first principal component accounted for $43.249 \%$ of the total variance; $\mathrm{Al}, \mathrm{Be}, \mathrm{Fe}, \mathrm{K}, \mathrm{Na}, \mathrm{Ti}, \mathrm{V}, \mathrm{Zn}, \mathrm{Cr}, \mathrm{Co}$, $\mathrm{Ni}$, and $\mathrm{Tl}$ had high positive loadings, $\mathrm{Ca}$ and $\mathrm{Sr}$ had high negative loadings in the component matrix. $\mathrm{Al}$ is a typical lithogenic element and a major constituent of common silicate minerals (Price et al., 1999). Correlation coefficients between $\mathrm{Al}$ and $\mathrm{Be}, \mathrm{Fe}, \mathrm{K}, \mathrm{Na}, \mathrm{Ti}, \mathrm{V}, \mathrm{Zn}, \mathrm{Cr}$, $\mathrm{Co}, \mathrm{Ni}$, and $\mathrm{Tl}$ were significantly positive. This relationship indicated that these elements primarily represent a lithogenic origin from weathering and erosion of soil parent materials in the lake watershed (Wilcke et al., 1998). The significant relationship between $\mathrm{Ca}$ and TIC indicated that $\mathrm{Ca}$ originated mainly from carbonate. Between 41 and $23 \mathrm{~cm}$, there were abundant biogenic shells in the sediment, which likely indicated that
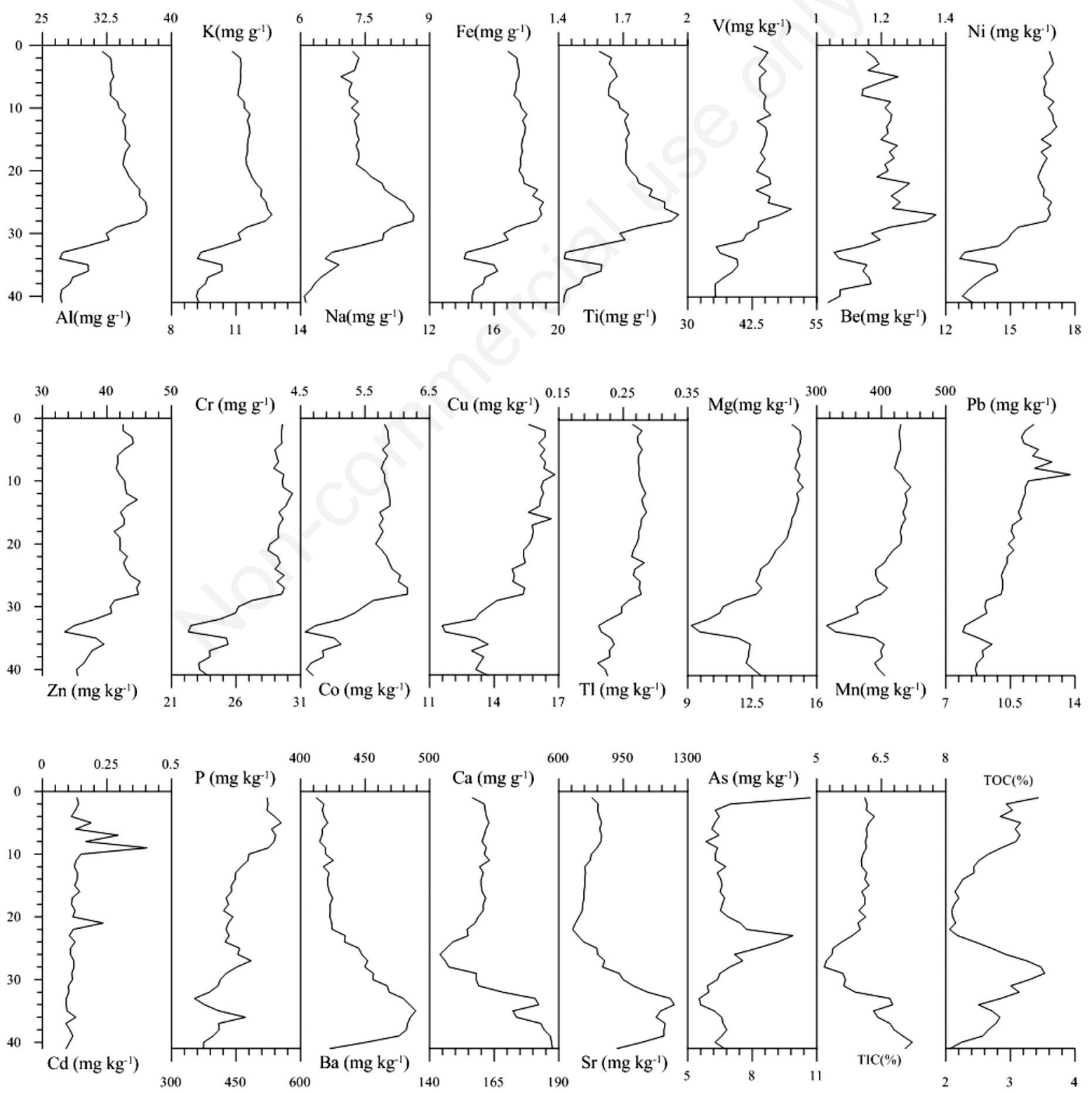

Fig. 3. Geochemical element profiles of the sediment core from Bosten Lake. 
biological carbonate was one of the main sources of $\mathrm{Ca}$ and Sr. The carbonate in the sediment was mainly autogenous (Yu et al., 2015). The geochemical behaviors of $\mathrm{Sr}$ and $\mathrm{Ca}$ in the supergene environment were largely consistent, and there was a significant correlation between them. Therefore, we regarded that $\mathrm{Ca}$ and $\mathrm{Sr}$ in the sediment core were mainly from endogenetic carbonate. The negative relationship of $\mathrm{Al}, \mathrm{Be}, \mathrm{Fe}, \mathrm{K}, \mathrm{Na}, \mathrm{Sr}, \mathrm{Ti}, \mathrm{V}$, $\mathrm{Zn}, \mathrm{Cr}$, and $\mathrm{Tl}$ with $\mathrm{Ca}$ and $\mathrm{TIC}$ in the lake sediments implied dilution effects of carbonate in the sediments. The first principal component can be explained as the combined effects of terrigenous detritus and endogenetic carbonate.

The second principal component accounted for $32.787 \%$ of the total variance. $\mathrm{Mg}, \mathrm{Mn}, \mathrm{Cr}, \mathrm{Cu}, \mathrm{Tl}, \mathrm{Pb}$ and clay content had high positive loadings, $\mathrm{Ba}, \mathrm{Sr}$, silt and sand content had distinct negative loadings in the component matrix. There were significant positive correlations of $\mathrm{Mg}, \mathrm{Mn}, \mathrm{Cr}, \mathrm{Ni}, \mathrm{Cu}, \mathrm{Tl}$, and $\mathrm{Pb}$ with clay content, and negative correlations with silt and sand content, while $\mathrm{Ba}$ and $\mathrm{Sr}$ were the opposite. $\mathrm{Ba}$ and $\mathrm{Sr}$ were significantly correlated; therefore, it was determined that they were roughly homologous in the lake sediment. The second principal component can be explained as the granularity effects of the lake sediment.

The third principal component accounted for $11.580 \%$ of the total variance. Matrix loadings of $\mathrm{P}, \mathrm{Cd}$ and $\mathrm{Pb}$ were high and positive. Under natural conditions, $\mathrm{P}$ was leached out from the minerals during the process of weathering, a portion was precipitated as calcium phosphate, and a portion was washed away by water. With the development of agriculture, the input of fertilizers was another important source of phosphorus. Agricultural phosphorus

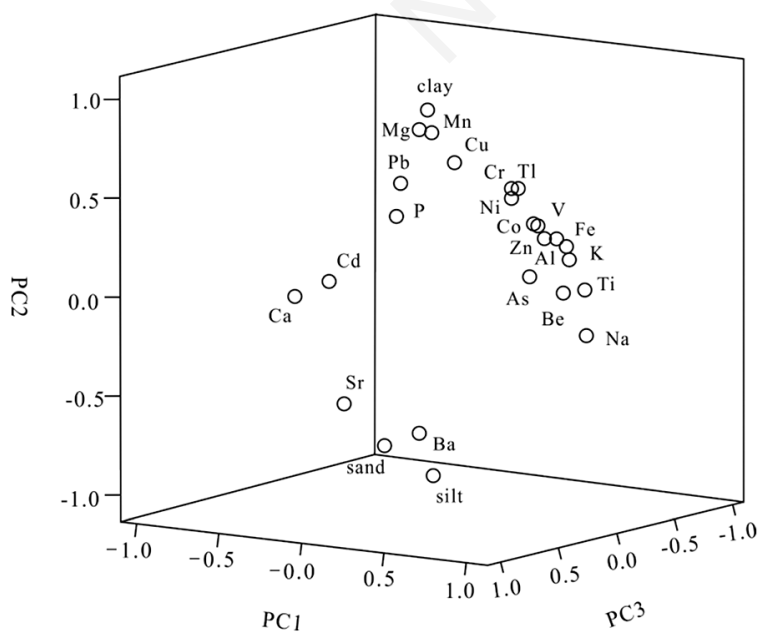

Fig. 4. PCA scores plot of geochemical elements in the sediment core of Bosten Lake. impurities not only contained high Cd but also contained a certain amount of $\mathrm{Pb}$ and other heavy metals (Taylor, 1997; Shi et al., 2008). As shown in Fig. 5, P, Pb and Cd have had higher enrichment factors during the past several decades, which indicated that they were clearly influenced by human activities. Furthermore, according to the study of Mamat et al. (2014), the $\mathrm{Pb}$ and $\mathrm{Cd}$ contents of the soil from Yanqi Basin were higher than the background values of Xinjiang and were obviously influenced by human activities. Zhang et al. (2009b) studied heavy metal contamination and found that $\mathrm{Pb}$ and $\mathrm{Cd}$ have been enriched obviously over the past several decades in the northwesten part (Huangshuigou area) of Bosten Lake. The third principal component can be explained as the impacts of human activities.

\section{Environmental state during the past 150 years}

According to the comprehensive analysis of element profiles, the environmental state of Bosten Lake during the past $\sim 150$ years can be divided into three stages as follows (Fig. 5).

The first stage was from the 1870 s to the 1950s. Bosten Lake was in a natural state in this stage. Experts and scholars basically formed a consistent view that the ecological environment of Bosten Lake was rarely influenced by human activities before 1958 (Zhou et al., 2001). Trace element concentrations in sediments were mainly driven by the watershed weathering and unpolluted natural atmospheric deposition. The element concentrations in this stage can be regarded as natural background levels. The concentrations of $\mathrm{Ca}, \mathrm{Ba}$ and $\mathrm{Sr}$ were high, while concentrations of other elements such as $\mathrm{Al}, \mathrm{K}$ and $\mathrm{Fe}$ were relatively low. The deposition rates were low, as calculated in this stage. During the mid1950 s, the hydrochemistry type was $\mathrm{HCO}_{3}{ }^{-} \mathrm{Ca}^{2+}-\mathrm{Mg}^{2+}$, in accordance with the water type in the basin ( $\mathrm{Li}$ and Yuan, 2002; Xiao et al., 2015). Mollusks were abundant before the 1960s (Li et al., 1987), which was also evidenced by the great number of biogenic shells and high $\mathrm{Ca}$ concentrations in the sediment core.

The second evolution stage was between the 1960s and the 1990s. Agricultural activities and land expansion had been developed in the basin and the lake received return water for the treatment of saline-alkali soils (Zhou et al., 2001). The concentrations of $\mathrm{Al}, \mathrm{Fe}, \mathrm{Mn}$, etc. have been greatly increased compared to the former stage. Along with the agricultural return water from Yanqi Basin, which was constantly discharged into the lake, the water type of the lake has changed to $\mathrm{SO}_{4}{ }^{2-} \mathrm{Cl}^{-} \mathrm{Na}^{+}$, which was consistent with the chemical type of drainage water (Zhou et al., 2001; Li and Yuan, 2002), and finally led to the mass mortality of mollusks (Li et al., 1987), as evidenced by the disappearance of biogenic shells in the sediment core. $\mathrm{Ca}, \mathrm{Sr}$ and $\mathrm{Ba}$ exhibited abrupt decreases 
after the 1960s, which can probably be attributed to the decrease of biogenic carbonate. As the basins from arid regions are vulnerable to soil erosion (Battarbee et al., 1985), the sediment deposition rates were obviously higher in this stage. The obvious peak of As in this period was probably because of the early diagenetic effect of the lake sediment (Carbonell-Barrachina et al., 1999).

The third stage was since the 2000s. The impacts of human activities on the lake evolution have been strengthened since the previous two stages. Economics has led to rapid development in this stage (Fig. 5). The lake water has been polluted, eutrophicated, and salinized, and the water quality was between type III-IV (Wu et al., 2013b). The increasing accumulations of heavy metals $(\mathrm{Cd}, \mathrm{Pb})$ and $\mathrm{P}$ with higher EFs in this stage were in accordance with the increase of agriculture, industrial pollution and domestic wastewater inputs (Yuan and Yang, 2008; Sai et al., 2012). The decline of sedimentation rate during recent years was likely because the saline-alkali soil treatment methods have greatly improved compared to the former stage (Chen et al., 2007) and the government have been conscious of the importance of regional environmental protection and promulgated relevant regulations (Wang et al., 2004), thus leading to the decrease of detrital matter in the lake.

In arid region, during the past centuries, especially since 1950s, the obvious increase of water consumption and the imported pollutants have led to a series of environmental problems, like lake shrinkage, pollutants input, eco-environment degeneration and so on (Micklin 1988; Fan et al., 2000; Lioubimtseva and Henebry, 2009). Lake Chaiwopu and Lake Ebinur in northewest China were two lakes which were greatly influenced by human activities during the past century. Through the study of sediment geochemistry of Lake Chaiwopu, the author found that due to a large number of water exploration, the enrichment of $\mathrm{Ca}$ and $\mathrm{Mg}$ were replaced by the enrichment of $\mathrm{Na}$, which was in accordance with the transition of water type, furthermore, $\mathrm{Pb}$ and $\mathrm{P}$ has been enriched during the past decades (Liu et al., 2016). In Lake Ebinur, the declined of water level and condensed of water salinity were in agreement with the accumulation of $\mathrm{Na}$ and $\mathrm{Mg}$ and the reduction of $\mathrm{Ca}$ and $\mathrm{Sr}$, while the heavy metals have not enriched in the sediment core (Ma et al., 2016; Liu et al., 2017). Sediment geochemistry has faithfully recorded the impacts of human activities on the environmental changes of arid lakes.

\section{CONCLUSIONS}

Principal component analysis combined with correlation analysis was used to identify the controlling factors of geochemical elements in Bosten lake sediments. The first controlling factor was the combination effect of terrigenous detritus and endogenous carbonate, supported by the high positive scores of $\mathrm{Al}, \mathrm{Be}, \mathrm{Fe}, \mathrm{K}, \mathrm{Na}, \mathrm{Ti}, \mathrm{V}, \mathrm{Zn}$,

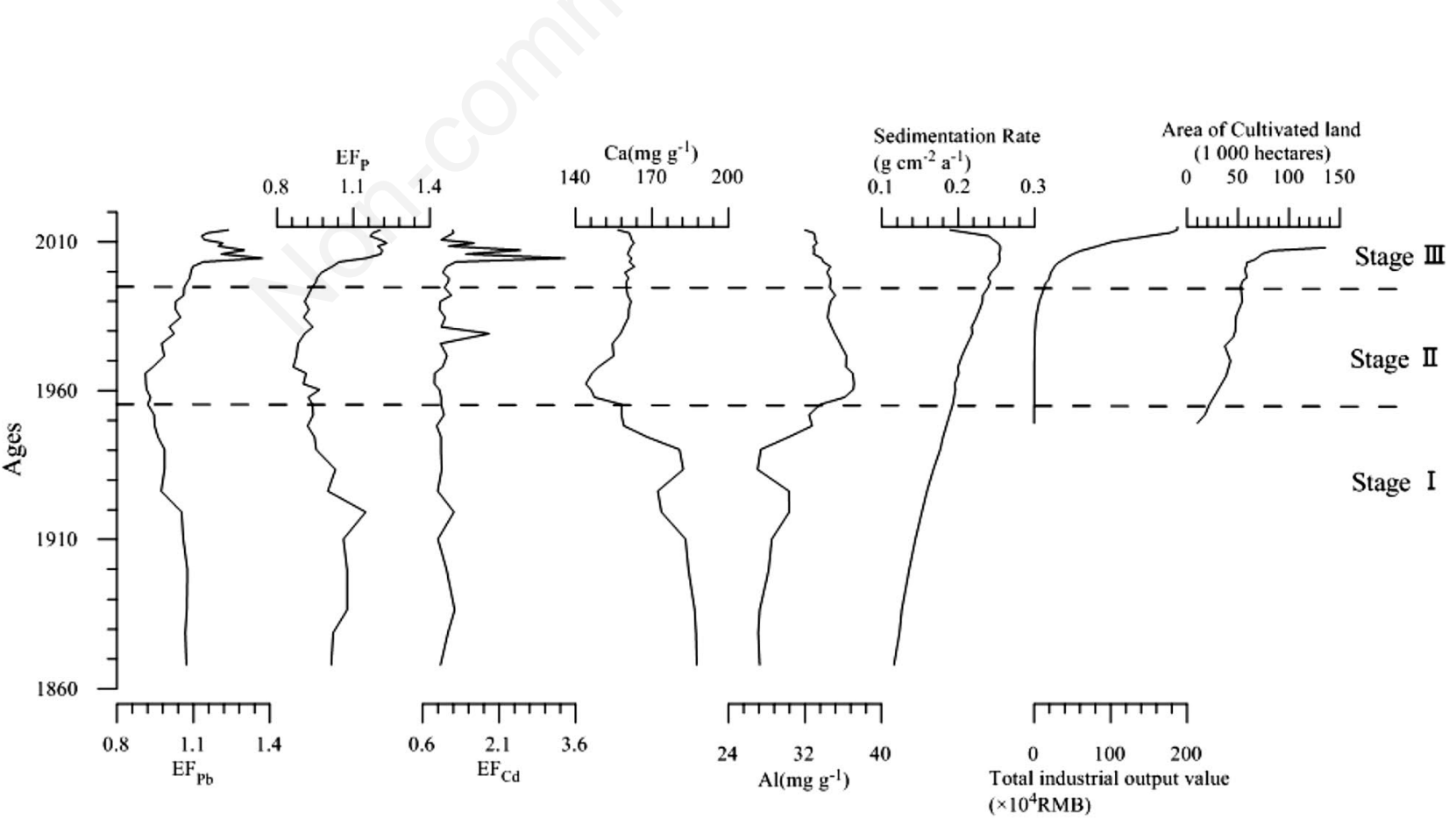

Fig. 5. Evolution stages of Bosten Lake during the past 150 years. The background values from elemental profiles were calculated as the average concentration before 1960, and Al was used as the reference element in EF calculations (Schropp et al., 1990; Ma et al., 2016). The total industrial output value and the Area of Cultivated Land were extracted from the Xinjiang Statistical Yearbook. 
$\mathrm{Cr}, \mathrm{Co}, \mathrm{Ni}, \mathrm{Cu}, \mathrm{Tl}$ and the high negative scores of $\mathrm{Ca}$ and $\mathrm{Sr}$. The second controlling factor was the granularity effects of the lake sediment, supported by the high positive scores of $\mathrm{Mg}, \mathrm{Mn}, \mathrm{P}, \mathrm{Cr}, \mathrm{Ni}, \mathrm{Cu}, \mathrm{Tl}, \mathrm{Pb}$ and clay content, and the high negative scores of $\mathrm{Ba}, \mathrm{Sr}$, silt and sand content. The third controlling factor was the inputs of human activities, as evidenced by the high positive scores of $\mathrm{Pb}, \mathrm{Cd}$ and $\mathrm{P}$.

Based on a comprehensive analysis of geochemical elements, the environmental state of Bosten Lake during the past $\sim 150$ years can be divided into three stages. The first stage was from the 1870 s to the 1950 s, the lake was in a natural state, and the deposition rate was relatively low. $\mathrm{Ca}, \mathrm{Sr}$, and $\mathrm{Ba}$ concentrations were relatively high, and biogenic shells were abundant in the sediment. The second stage was between the 1960s and the 1990s, the agricultural return water caused high deposition rates of the sediment in this stage, the concentrations of $\mathrm{Ca}, \mathrm{Ba}$, and $\mathrm{Sr}$ had declined and biogenic shells had disappeared due to the increased salinity. The third stage comprised the period since the 2000s, with the rapid development of society and economy in the basin, the enrichments of $\mathrm{P}$, $\mathrm{Cd}$, and $\mathrm{Pb}$ in the lake sediment were probably derived from human inputs. The deposition rates have begun to decline in recent years of this stage.

\section{ACKNOWLEDGMENTS}

We thank the funding supports of West Light Foundation of the Chinese Academy of Sciences (NO.2015-XBQN-B-18), the National Natural Science Foundation of China (NO. 41501221), and the HighLevel Talents Introduction Project in Xinjiang Uygur Autonomous Region, China (2015). We thank Yongxiao GE and Hao SHEN for filed sampling work.

\section{REFERENCES}

Appleby P, 2008. Three decades of dating recent sediments by fallout radionuclides: a review. Holocene 18:83-93.

Battarbee RW, Appleby PG, Odell K, Flower RJ, 1985. ${ }^{210} \mathrm{~Pb}$ dating of Scottish lake sediments, afforestation and accelerated soil erosion. Earth Surf. Proc. Land 10:137-142.

Boyle JF, Rose NL, Appleby PG, Birks HJB, 2004. Recent environmental change and human impact on Svalbard: the lake-sediment geochemical record. J. Paleolimnol. 31:515530.

Carbonell-Barrachina A, Jugsujinda A, Delaune R, Patrick Jr W, Burló F, Sirisukhodom S, Anurakpongsatorn P, 1999. The influence of redox chemistry and $\mathrm{pH}$ on chemically active forms of arsenic in sewage sludge-amended soil. Environ. Int. 25:613-618.

Chen F, Huang X, Zhang J, Holmes J, Chen J, 2006. Humid little ice age in arid central Asia documented by Bosten Lake, Xinjiang, China. Sci. China Ser. D. 49:1280-1290.
Chen F, Yu Z, Yang M, Ito E, Wang S, Madsen DB, Huang X, Zhao Y, Sato T, Birks HJB, 2008. Holocene moisture evolution in arid central Asia and its out-of-phase relationship with Asian monsoon history. Quaternary Sci. Rev. 27:351364.

Chen J, Zhang E, Brooks SJ, Huang X, Wang H, Liu J, Chen F, 2014. Relationships between chironomids and water depth in Bosten Lake, Xinjiang, northwest China. J. Paleolimnol. 51:313-323.

Chen X, Yang J, Hu S, 2007. [Water resources development and control of soil secondary salinization in Yanqi Basin].[Article in Chinese]. Chinese J. Soil Sci. 38:233-237.

Fan Z, Hu W, Ji F, Wang R, Ma Y, Ma Y, 2000. [Problems, protection and improvement of ecological environment in Xinjiang].[Article in Chinese]. Arid Land Geogr. 23:298303.

Grosbois C, Meybeck M, Lestel L, Lefevre I, Moatar F, 2012. Severe and contrasted polymetallic contamination patterns (1900-2009) in the Loire River sediments (France). Sci. Total Environ. 435-436:290-305.

Guo M, Wu W, Zhou X, Chen Y, Li J, 2015. Investigation of the dramatic changes in lake level of the Bosten Lake in northwestern China. Theor. Appl. Climatol. 119:341-351.

Huang X, Chen F, Fan Y, Yang M, 2009. Dry late-glacial and early Holocene climate in arid central Asia indicated by lithological and palynological evidence from Bosten Lake, China. Quatern. Int. 194:19-27.

Li S, Han Y, Guo C, 1987. [The causes of ecological deterioration and control measures in Bosten Lake, Xinjiang] [Article in Chinese]. Water Resour. Prot. 4:78-82.

Li W, Yuan L, 2002. [On the water-salt change of Bosten Lake in Xinjiang].[Article in Chinese]. J. Lake Sci. 14:223-227.

Liao H, Bu W, Zheng J, Wu F, Yamada M, 2014. Vertical distributions of radionuclides $\left({ }^{239+}{ }^{240} \mathrm{Pu},{ }^{240} \mathrm{Pu} /{ }^{239} \mathrm{Pu}\right.$, and ${ }^{137} \mathrm{Cs}$ ) in sediment cores of Lake Bosten in Northwestern China. Environ. Sci. Technol. 48:3840-3846.

Lioubimtseva E, Henebry GM, 2009. Climate and environmental change in arid Central Asia: Impacts, vulnerability,and adaptations. J. Arid Environ. 73:963-977.

Liu W, Wu J, Pan X, 2016. A 100-year record of climate change and human activities inferred from the geochemical composition of sediments in Chaiwopu Lake, arid northwest China. J. Limnol. 75:1301.

Liu W, Ma L, Wu J, Abuduwauli J, 2017. Environmental variability and human activity over the past 140 years documented by sediments of Ebinur Lake in arid central Asia. J. Limnol. 76:534-545.

Liu Y, Mu S, Bao A, Zhang D, Pan X, 2015. Effects of salinity and (an) ions on arsenic behavior in sediment of Bosten Lake, Northwest China. Environ. Earth Sci. 73:4707-4716.

Ma L, Wu J, Abuduwaili J, Liu W, 2016. Geochemical responses to anthropogenic and natural influences in Ebinur Lake sediments of arid Northwest China. PloS One 11:e0155819.

Mamat Z, Yimit H, Ji RZ, Eziz M, 2014. Source identification and hazardous risk delineation of heavy metal contamination in Yanqi basin, northwest China. Sci. Total Environ. 493:1098-1111

Micklin PP, 1988. Desiccation of the aral sea: a water management disaster in the soviet union. Science 241:11701176. 
Mischke S, Wünnemann B, 2006. The Holocene salinity history of Bosten Lake (Xinjiang, China) inferred from ostracod species assemblages and shell chemistry: possible palaeoclimatic implications. Quatern. Int. 154:100-112.

Morillo J, Usero J, Gracia I, 2004. Heavy metal distribution in marine sediments from the southwest coast of Spain. Chemosphere 55:431-442.

Price N, Brand T, Pates JM, Mowbray S, Theocharis A, Civitarese G, Miserocchi S, Heussner S, Lindsay F, 1999. Horizontal distributions of biogenic and lithogenic elements of suspended particulate matter in the Mediterranean Sea. Prog. Oceanogr. 44:191-218.

Rusuli Y, Li L, Ahmad S, Zhao X, 2015. Dynamics model to simulate water and salt balance of Bosten Lake in Xinjiang, China. Environ. Earth Sci. 74:2499-2510.

Sai B, Chen M, Feng L, 2012. [Agricultural non-point source pollution of Bosten Lake Basin].[Article in Chinese]. Water Resour. Prot. 28:25-29.

Shi H, Song W, Zhao Z, 2008. [The current conditions and causes of agricultural soil pollution in China].[Article in Chinese]. Acta Agricult. Shanghai 24:122-126.

Schropp SJ, Graham LF, Windom HL, Ryan JD, Calder FD, Burney LC, 1990. Interpretation of metal concentrations in estuarine sediments of Florida using aluminum as a reference element. Estuar. Coast 13:227-235.

Statistical Bureau of Xinjiang Uygur Autonomous Region, 1950-2017. Xinjiang Statistical Yearbook. China Statistics Press, Beijing Info Press, Beijing.

Taylor M, 1997. Accumulation of cadmium derived from fertilisers in New Zealand soils. Sci. Total Environ. 208:123-126.

Wünnemann B, Mischke S, Chen F, 2006. A holocene sedimentary record from Bosten Lake, China. Palaeogeogr. Palaeocl. 234:223-238.

Wang S, Dou H,. 1998. [Lakes in China].[Book in Chinese]. Science Press.

Wang X, Gong P, Zhao Y, Xu Y, Cheng X, Niu Z, Luo Z, Huang H, Sun F, Li X, 2013. Water-level changes in China's large lakes determined from ICESat/GLAS data. Remote Sens. Environ. 132:131-144.

Wang Y, Li Y, Tan Y, 2004. [Analysis on the evolution trend of the aqueous environment of Bosten Lake in Xinjiang].[Article in Chinese]. J. Arid Land Resour. Environ. 18:61-65.

Wilcke W, Müller S, Kanchanakool N, Zech W, 1998. Urban soil contamination in Bangkok: heavy metal and aluminium partitioning in topsoils. Geoderma 86:211-228.

Wu J, Ma L, Yu H, Zeng H, Liu W, Abuduwaili J, $2013 \mathrm{a}$.
Sediment geochemical records of environmental change in Lake Wuliangsu, Yellow River Basin, north China. J. Paleolimnol. 50:245-255.

Wu J, Ma L, Zeng H, 2013b. Water quality and quantity characteristics and its evolution in Lake Bosten, Xinjiang over the past 50 years. Sci. Geogr. Sin. 33:231-237.

Xiao J, Jin Z, Wang J, Zhang F, 2015. Major ion chemistry, weathering process and water quality of natural waters in the Bosten Lake catchment in an extreme arid region, NW China. Environ. Earth Sci. 73:3697-3708.

Xiao M, Wu F, Liao H, Li W, Lee X, Huang R, 2010. Characteristics and distribution of low molecular weight organic acids in the sediment porewaters in Bosten Lake, China. J. Environ. Sci. 22:328-337.

Yang H, Rose N, 2005. Trace element pollution records in some UK lake sediments, their history, influence factors and regional differences. Environ. Int. 31:63-75.

Yu Z, Wang X, Fan H. 2018. Spatial distribution of organic carbon in surface sediment of Bosten Lake, p. 103-115. In: X. Wang, Z. Yu, J. Wang and J. Zhang (eds.), Carbon cycle in the changing arid land of China. Springer.

Yu Z, Wang X, Zhao C, Lan H, 2015. Carbon burial in Bosten Lake over the past century: impacts of climate change and human activity. Chem. Geol. 419:132-141.

Yuan X, Yang D, 2008. [Study on the aqueous environment problems of the Bosten Lake, Xinjiang].[Article in Chinese]. Arid Zone Res. 25:735-740.

Zhang C, Mischke S, Zheng M, Prokopenko A, Guo F, Feng Z, 2009a. Carbon and Oxygen Isotopic Composition of Surface $\square$ Sediment Carbonate in Bosten Lake (Xinjiang, China) and its Controlling Factors. Acta Geolsin-Engl. 83:386-395.

Zhang G, Xie H, Yao T, Kang S, 2013. Water balance estimates of ten greatest lakes in China using ICESat and Landsat data. Chinese Sci. Bull. 58:3815-3829.

Zhang Y, Wu F, Zhang R, Liao H, Ling H, 2009b. [Sediment records of heavy metal pollution in Bosten Lake, Xinjiang].[Article in Chinese]. Earth Environ. 37:50-55.

Zhou C, Luo G, Li C, Tang Q, Li H, Wang Q, Fukui H, 2001. [Environmental change in Bosten Lake and its relation with the oasis reclamation in Yanqi Basin].[Article in Chinese]. Geograph. Res. 20:14-23.

Zhou H, Li W, Chen Y, Fu A, 2014. [Water-salt succession patterns (1951-2011) and its response to climate change in Lake Bosten].[Article in Chinese]. J. Lake Sci. 26:55-65.

Zuo Q, Dou M, Chen X, Zhou K, 2006. [Physically-based model for studying the salinization of Bosten Lake in China].[Article in Chinese]. Hydrol. Sci. J. 51:432-449. 